Relations industrielles

Industrial Relations

\title{
Labour Democracy in 1952
}

\section{Emile Gosselin}

Volume 8, numéro 1, décembre 1952

URI : https://id.erudit.org/iderudit/1022983ar

DOI : https://doi.org/10.7202/1022983ar

Aller au sommaire du numéro

\section{Éditeur(s)}

Département des relations industrielles de l’Université Laval

ISSN

0034-379X (imprimé)

1703-8138 (numérique)

Découvrir la revue

Citer cet article

Gosselin, E. (1952). Labour Democracy in 1952. Relations industrielles / Industrial Relations, 8(1), 125-144. https://doi.org/10.7202/1022983ar
Résumé de l'article

In the first section, the author comments briefly on the nature and the importance of the annual conventions of the Canadian labour bodies and on their political action. The reader will find in the second section a summary of the speeches, reports and resolutions presented during these conventions.
Tous droits réservés (C Département des relations industrielles de l’Université Laval, 1952
Ce document est protégé par la loi sur le droit d'auteur. L’utilisation des services d'Érudit (y compris la reproduction) est assujettie à sa politique d'utilisation que vous pouvez consulter en ligne.

https://apropos.erudit.org/fr/usagers/politique-dutilisation/ 


\title{
Labour Democracy in 1952
}

\author{
Emile Gosselin
}

In the first section, the author comments briefly on the nature and the importance of the annual conventions of the Canadian labour bodies and on their political action. The reader will find in the second section a summary of the speeches, reports and resolutions presented during these conventions.

\section{I-LABOUR CONVENTIONS}

The three great labour organizations of Canada have held their annual conventions during the months of August and September. From August 18th to 23rd, 5.37 delegates of the Trades and Labour Congress, representing more than a half million members (about 523,000) met at Winnipeg, under the presidency of Mr. Percy R. Bengough. It was the fifth time that this prodigious city of the Canadian West received the delegates of our largest labour body. The second convention, held from September 14th to 18th, brought together at Shawinigan Falls, under the presidency of Mr. Gérard Picard, the 400 delegates of the dynamic Canadian and Catholic Confederation of Labour, grouping 95,000 members, which is the most important labour movement in our Province. Finally, the Queen City welcomed the 934 delegates of the Canadian Congress of Labour, the most imposing delegation of all the conventions held this year. It is to be noted that it is at Toronto itself that, in September 1940, the Canadian Congress of Labour was born. It was therefore with considerable satisfaction that the president, Mr. A. R. Mosher, could look back on the work done by the labour organization, which today takes second place among our movements with more than 330,000 members.

GOSSELIN, Emile, Master of Law (Montreal), M.A. in Economics (Toronto), Secretary of the Industrial Relations Department of Laval University, in charge of the course of Economics of Labour and Director of industrial relations research. 


\section{Importance of Conventions}

The conventions of our labour organizations have as general aims to enlighten and direct the delegates as well as allowing them to participate in a democratic way in the life of the movement. A convention permits the members to reinforce the bonds of fellowship that brings them together in the pursuit of common objectives. During these meetings, the problems of organization which arise in different districts of the country are discussed and the movement is given its true orientation. Principles are reasserted and action techniques are submitted to careful scrutiny. It is also during these annual meetings that the positions of organized labour towards economic, political and social problems which affect the workers' world may be carefully examined. These problems after all are very important aspects of the life itself of the nation.

It is with reason that the press, radio and news agencies describe, comment on or criticize the various phases of these meetings, because the union movement is closely connected with the progress of the country itself. The union problems cannot be treated in a closed retort. If the speeches and debates which take place at these occasions are analyzed, the anxiety to reach all the public, citizens as well as the government, to draw them into the heart itself of the problem, can be noted. To sum it up, the conventions are meant for both the members of labour organizations and the citizens of the country, of the Province, It is therefore before an audience much larger than that made up of the delegates themselves that the debates on labour problems really take place.

\section{Political Action}

Every year the country's labour organizations inform the different governments of their viewpoints on certain aspects of the provincial or national politics and they put pressure to have these governments adopt programmes which conform to the best interests of the working class. However, many workers, in particular the members of many labour organizations, have come to the conclusion that political orientation restricted to civic education only or to the simple presentation by the unions of their grievances or their demands, does not give the desired results because they come too slowly, whereas the problems of labour are urgent. The present attitude of organized labour is to exercise in the future, by appropriate methods in conformity with true unionism acting in the modern state, an influence, much more direct on the public and 
the government by direct non-partisan political action. This is not new in our union records, but two conventions, that of the C.C.L. and the C.C.C.L. have stated it this year with such force and conviction, that a profound change may be glimpsed in the orientation of all our labour movements.

\section{The opinion of the conventions on political action}

Mr. Mosher of the C.C.L. stated, in his presidential address at Toronto: "I should like to repeat my conviction that the next great advance on the part of the Canadian Labour movement must be in the political field. We have not begun to realize the potentialities of our political strength, and, as a result, the interests of the workers, so far as labour legislation is concerned, have not received the attention which they deserve."

Further on in his speech, the president indicates some reasons, which in his opinion, justifies union political action: "The old political parties claim to be representative of the people, but they are actually responsible to the private interests which provide campaign funds and control political policies. The only remedy for this state of affairs is for the workers to become organized in the political field as well as in the economic field, and to elect their own representatives to Parliament and the provincial legislatures."

Taking up this problem in his moral report, Mr. Gérard Picard, president of the Canadian and Catholic Confederation of Labour, declared to the 400 delegates brought together at Shawinigan: "In the attainment of its aim, which is, in general terms, the study, the protection and promotion of the professional, economic and social interests of its members, a labour union organization has the right to use all honest means that will permit it to reach it. It must avoid, and this is elementary, that use of any method, no matter if it is honest, does not turn it away from its purpose."

"There is no absolute necessity for a workers' union organization to act politically. But when labour legislation and its application become a source of injustice, when the government shows itself to be hostile to labour unions or to be able to support so badly any contradiction that it is constantly looking for a chance to retaliate against union leaders, political action may become necessary, of a necessity of method, in order to awaken public opinion. What is anti-democratic about this ? And even if, during an electoral campaign, the political action of the 
unions leads to declarations judged to be ill-timed, even a little too audacious, this could be sufficient reason to call them to order, but not a sufficient reason to put aside political action as a resort of unions when other methods have not given satisfactory results."

This declaration becomes clear when it is taken with another reflection that Mr. Picard makes elsewhere in his presidential address: "the political action of labour unions diminishes in intensity when an atmosphere of confidence exists and when labour legislation is prepared and administered in accordance with the tripartite formula which provides for the cooperation of the State, the employers' associations and the labour unions. As the founders of the International Labour Organization put it, in 1919:

"The social life cannot and must not be ruled by governments in the proud sterile of their sovereignty."

"Here the atmosphere of confidence does not exist and there has been tension in the situation for several years. Moreover, the tripartite formula is not accepted, in the concrete form, in order to ensure the preparation and the application of labour legislation. Can this state of affairs be corrected? It should be even more possible in a Catholic province than elsewhere. Why cannot we succeed? Let us take two or three cases among a hundred and we should finally understand ourselves."

The new union political orientation is not only a simple gesture of protection against acts in opposition to unionism itself. This political action, according to Messrs. Mosher and Picard, seems in conformity with the best interests of unionism and of the workers and is based on the necessities itself of the movement and its aims. Let us quote here, the general moral advisor of the C.C.C.L., the Canon Henri Pichette. After having asked the meeting if it should keep out of politics "to the extent of limiting ourselves to particular welfare without seeing the welfare of all society ?" Canon Pichette continued: "It would be false and we would be wrong, under the pretext that it would be a delicate problem, to ignore it. The social problem is one of relations between individuals and all classes of society and it is our duty to add our contribution. Our unionism has an aim that is professional and economic. This is its proper aim but it is not limited to this, cut off from the rest, and it cannot be separated from all the other problems of society without taking the risk of falsifying it. If we are part of a whole and we must form this whole with others, we cannot ignore them and separate 
ourselves from them under the pretext that it is not our sphere. It is up to you, therefore, to take political action because, otherwise, you would not be the prime builders of your own restoration and your integration or you would expose yourselves to be ignored by the others. It is up to you then, to consider, at the same time, all the circumstances in which your political action must take place. You cannot ignore the past. You cannot fail to recognize the state of mind, but you cannot at the same time avoid the responsibilities that fall on you to cooperate with the others in the political field to allocate a place and to integrate the working class. In this task, you will help to give again to politics all the nobility that it should have."

\section{Political Action Announced at the Conventions}

C.C.L.:

The C.C.L. prepares a political programme and submits it to all the political parties. It does not affiliate with any party, but it 'endorses" momentarily the party and the candidates which accept the political programme of the movement. It intends to remain independen of all parties even if at a given time it grants as a movement, a formal support to a party or candidates. It tries to stimulate among workers their political candidature and it accepts that members take on of their own free will positions of command in a party. At the present time the C.C.L. endorses the policy of the C.C.F. party and recommends that its members support it.

\section{T.L.C.:}

Nothing would indicate in reports which have reached us so far, that the subject was discussed this year in the same way as was done by the C.C.L. and the C.C.C.L. Let us recall, however, the traditional policy of this movement to leave full liberty to the unions themselves and to favour a decentralized non-partisan policy on the local or provincial scale. This labor movement favours the development of local or provincial political committees. On occasion, the unions support measures or candidates favourable to the movement.

C.C.C.L.:

a) The declaration of Mr. Picard to the Convention: "During the last few months, there has been so much confusion in regard to the attitude of the C.C.C.L. that it is important to clarify once for all the 
situation. The C.C.C.L. has not founded and is not thinking about founding a political party. There is no organic bond between any political party and the C.C.C.L. As the result, however, political action within the C.C.C.L $L_{v}$ could have favoured, and has, as a matter of fact, favoured certain candidates of a political party, as it has caused the defeat of certain candidates of another political party." Farther on, he added: "It must not be concluded from what has preceded ${ }^{1}$ that the C.C.C.L. is anxious to undertake direct and non-partisan political action. But the C.C.C.L. without going as far as most of the workers' union organizations in other democratic countries, has considered that it should take the road of political action, without, however, joining its destiny to that of any political party."

After having made numerous suggestions concerning an industrial relations committee in the Legislative Assembly and a permanent list of arbitration council presidents, Mr. Picard continued: "It seems that the C.C.C.L. should maintain its Committee of political orientation and favour the formation of regional and local committees acting together with the provincial committee." A subject like the revision of the electoral map of the Province of Quebec could be dealt with by all the committees at the same time.

\section{b) Resolutions:}

The delegates adopted resolutions of which here are a few important points:

1) The committee of political orientation will make known "in the paper Le Travail the attitudes favourable or not to the workers, of the politicians."

2) In future the paper Le Travail will refuse to publish any advertisement of a political party.

3) Adoption of the resolution of the Bureau Confederal ${ }^{2}$ on the political action, dated March 27, 1952, where it is stated, in part:

A. The C.C.C.L., as such, will not support any candidate, nor any political party;

B. The officers and members of the Bureau Confederal, with the exception of the general president and the general secretary who, be-

(1) Former political action within the C.C.C.L.

(2) See this resolution in the section "information". 
cause of their functions, involve more directly the C.C.C.L., will be free to exercise all the rights conferred by their title of citizen";

During the conventicn, Mr. Gérard Picard pointed out elsewhere the intention of this resolution in two points: 1) "that the general president and the general secretary do not become candidates without resigning their positions, 2) that they do not take part in any political meeting by the political parties."

4) Approval of the report of the general president and the Committee of political orientation on the questions concerning political action.

\section{Conclusions}

Without judging here political methods used in the union world, it may at least be said that the general orientation of the unions in the political sphere is in line not only with the reality of the facts but that it confirms the new conception which gives life to the union movement today. Unionism was born at a time when political theory proclaimed that the labour movement was only acceptable if it was limited to improving the lot of the worker by collective bargaining, with an occasicnal use of the right to strike. But this theory seems to be very incomplete today, even if it emphasizes two of the essential conditions to the survival and progress of a free and active unionism.

Government action constantly affects the worker and his union in things which are beyond the limits of the collective agreement and which can only be studied at their proper merit on the political plane. In reality, the economic and social life in which the modern worker lives is so complex and interdependent that everything that is political affects it." Because of this, it is essential that the workers' movements assert the rights of the workers and defend them in the political arena itself, by using the most appropriate techniques in the attainment of the general welfare and to the protection of the individual and collective interests of the workers.

\section{2-SYNOPSIS OF WORKERS' CONVENTIONS \\ Communism}

The three conventions have repeated their indomitable opposition to communism. Mr. Mosher, president of the C.C.L. expressed him-

(3) We shall discuss in more detail the orientation of unionism in the political field in a coming number of the Reriew. 
self in these words: "The Canadian Congress of Labour has not only cooperated in the fight against Communism in the international sphere but it has also been active in the fight against Communism in Canada itself. As you all know, the Congress expelled the Canadian branches of three international unions which were dominated by well-known Communists, and has actively supported legitimate Labour unions covering the industries in which these Communist-led unions had been organized. In the circumstances, there is no reason why any Canadian worker, should belong to a Communist union."

The question of communism brought up a very lively debate at the meeting of the T.L.C. The president, Mr. Percy Bengough, was very vehement: "We have our reactionaries who work for a system of govermment that bases its economy on slave labour... Too long have these Communists and their stooges, who seek to enslave us, posed as liberators. The time has arrived when this Congress as part of the free Trade-Union Movement must expose their treachery and duplicity. This Congress as an important part of the International Confederation of Free Trade Unions. . cannot, in all sincerity, do anything else but eliminate them from our organization here at home."

The C.C.C.L. is opposed in principle to communism. The president, Mr. Gérard Picard, as well as Mr. Jean Marchand, secretary of the Confederation and the delegates became indignant against certain insinuations in regard to the position of their movement towards communism. "An attempt has been made to make it appear that the C.C.C.L. was an ally of communism. It is useless to say that this campaign of disparagement is as false as it is ridiculous. It is obvious that this campaign has as aim to raise doubts and especially to hurt the reputation of the present directors of the movement."

"Because there is a Catholic church in Moscow, can it be pretended that the Vatican is an ally of the Kremlin ?" With subtle irony, the president disposes of numerous objections and finally explains the position of his movement. "The C.C.C.L. is opposed to communism by conviction not by fear. It is opposed to communism because communism is atheistic and has no respect for the human being and the family. The C.C.C.L. draws inspiration from the social doctrine of the Church and places spiritual values first in the scheme of things."

The C.C.C.L. repeats its submission to the social doctrine of the Church and intends to carry out its economic and social duty in spite 
of the fact that this movement "born and developing in a Catholic milieu, meets with such opposition and is victim of so much annoyance and has such difficulties in finding its rightful place in society."

\section{Inter-Congress Co-operation}

The formation of an inter-union combine with the view of presenting a united front at times of important labour demands, had raised much enthusiasm several months ago in union circles. But today the combine itself has disappeared, not because of a misunderstanding on the necessity of the combine itself, but because of the differences of opinion among the members of the combine on their respective methods of action.

In his Report, Mr. Jean Marchand, general secretary of the C.C.C.L., regrets that the inter-union combine "has not been able to resist certain disagreements. It is certainly in the best interest of the workers that the union organizations present a united front in certain particular circumstances."

Did Mr. Bengough, of the T.L.C. really regret the breaking-up of the combine following the refusal of his movement to prolong its existence? He affirms, openly at least, that the T.L.C. withdrew because of the acts of the C.C.L. "For a time, I felt that we were getting places; but there were no results. Although the committee seemed to be a pretty good proposition, I took strong objections to the C.C.L. who were trying to use the committee to undermine this organization. It became impossible to operate that committee." A union presented a resolution demanding unity among workers but it was voted down by the delegates after the words of Mr. Bengough in regard to the C.C.L. It would seem that the T.I.C. does not intend for the present to take the initiative of forming again the inter-congress co-operation committee.

There was considerable discussion at the C.C.L. meeting, in regard to the attacks of the T.L.C. on it. Mr. Donald McDonald especially, undertook to define the position of the congress of which he is secretarytreasurer, on the subject of Union co-operation. He mentioned the rebuffs and insults of the T.L.C., but he said: "We are ready and we are anxious to offer our friendship, but we refuse to betray the interests of our members. We wish to be equal partners." Further on he continued: "We have done everything possible to create again in Canada a single workers' organization, a congress speaking with one voice." In 
spite of the complaints laid by the C.C.L.'s delegates against the other union groups, particularly the T.L.C., the meeting voted by an overwhelming majority, a resolution recommending that the executive of the Congress open negotiations with the T.L.C. and C.C.C.L. in order to create a unity of action when it concerns "all questions interesting the Canadian workers."

\section{Union demands}

On the background itself of the problems which they must meet, as well as on the reform programmes, the union organizations show almost complete unanimity.

\section{a) Health Insurance}

A resolution presented to the delegates of the T.L.C. requests the Executive of this group to continue to press for a national plan of health insurance which would be subsidized and contributory. It would be a system "granting medical, surgical, optical, psychopathical and dental care, and appropriate hospitalization and nursing services, to all those who are in need of them", and for which the workers would accept a fair proportion of the expenses.

The delegates of the C.C.L. had to choose between different resolutions along the lines of the one adopted by the T.L.C. It was adopted unanimously, and without discussion a fairly general expression recommending "an appropriate system of health insurance in conformity with organized labour demands, of those of the Canadian Legion and other representative groups of citizens."

\section{b) Old Age Pensions}

The delegates of the T.L.C. requested the Executive to continue its efforts with the aim of obtaining better plans for old age and retirement pensions "so as to provide for the payment of a pension at 65 for men and 60 for women."

\section{c) Taxation}

The delegates to the three conventions were called on to decide on resolutions of which general contents were much the same.

\section{T.L.C.:}

A resolution including all the wishes expressed, requests the government, among other things, to permit deduction up to $10 \%$ of in- 
come, of all medical expenses as well as treatments prescribed, including dental and optical care. It would be the same for the cost, purchase price and upkeep of tools essential to the worker's occupation. Also that the income tax rate be scaled in accordance with the income in order that the rate be lowered for the groups receiving lower incomes. That income tax exemptions be as follows: married persons $\$ 3,000.00$; single persons $\$ 1,500.00$. That the exemption be raised from $\$ 250.00$ to $\$ 300.00$ in the case of married women whose husband works; that the family allowances be exempt from taxation. Finally, that overtime pay be exempt from income tax.

\section{C.C.L.:}

That all medical expenses, including doctors' prescriptions, be entirely deductable from income tax; that the following exemptions be granted: $\$ 3,000.00$ for married persons; $\$ 1,500.00$ for single persons and $\$ 300.00$ for each dependent; that the union dues paid be shown on the $\mathrm{T}-4$ forms, as is the case for pension funds.

\section{C.C.C.L.:}

The delegates to the Convention of Shawinigan adopted resolutions requesting that the amounts paid as premiums "for protection against sickness, accident or death, for a strike fund and for the levies made by parity committees on workers' wages be deductible from income tax." It was also requested that an exemption of $\$ 1,000.00$ from income "be granted to the one paying the expenses of a student as long as his studies are not finished, no matter what his age is." A resolution was also adopted demanding "that income tax on overtime be done away with, because of the scarcity of labour."

\section{d) Housing}

The report of the Housing Committee of the T.L.C. adopted unanimously, emphasizes the disappointment of the Congress with the reply of the Prime Minister of Canada to their request concerning housing. The Congress will continue its efforts in view of obtaining low-rental housing. A resolution requests that the rate of interest for the building and the purchase of houses be not more than $31 / 2 \%$ and that the necessary loans be granted through the National Housing Act.

Government policy on the housing question and the National Housing Act were severely criticized by many delegates of the C.C.L. A resolution was even sent back to the resolutions committee because 
it was not strong enough. This resolution accused the government of having failed in its task of satisfying the demand for rents for those who cannot build themselves houses. It requested the government, among other things, to take the necessary steps to satisfy the needs in the question of housing and in particular to make amendments to the National Housing Aot to provide loans at low interest rates as well as low down-payments, that loans should be made directly through the Central Mortgage and Housing Corporation to those who wish to build themselves a house. In this resolution, the Government was further asked to undertake large-scale low-rental housing projects in overcrowded urban centres.

Whereas the C.C.L. and the T.L.C. in regard to the question of housing, concentrate their efforts exclusively on government action, the C.C.C.L. in addition to putting pressure on the government also urged its members to act themselves. From the resolutions and recommendations presented at the C.C.C.L. convention, it may be seen that some concern the government and others the members.

To the government, it was requested that wage-earners be made to benefit from articles 9 and 35 of the National Housing Act and that an agreement to this end be made between the Federal, Provincial and Municipal authorities. A request was also made that the government take advantage of article 35 of the National Housing Act and prepare lots and build family housing units for rent or for sale. Another resolution was presented to it: the reinstatement of the additional loan of one-sixth of the combined loan to proprietors. A last request was that the Provincial Government permit the People's Savings Banks (Caisses Populaires) to employ $50 \%$ of their liquid reserves in loans on family houses, and that the government guarantee $50 \%$ of these loans.

As previously mentioned, the C.C.C.L. requested its members to act and to this end recommended, first, that an inquiry be made in order to know the situation of the members from the housing point of view: that a housing credit union be created among the members, of which the money would serve to finance temporarily any family housing construction plan. Another requests that the bodies affiliated with the C.C.C.L. favour or instigate the formation of limited dividend companies not exceeding $5 \%$, in order to take advantage of the article of the National Act. This article provides that the Central Mortgage and Housing Corp. may grant, at a rate of $3 \mathrm{r} / 2 \%$, loans up to $90 \%$ of the 
loan value for low-rental housing projects, when these loans are granted to limited dividend companies not exceeding $5 \%$.

\section{e) Immigration}

Many resolutions requiring a closer control of immigration were presented during the C.C.L. convention. A recommendation was substituted for these requesting the Government to create an immigration consultative committee including a fair labour representation, in order to "maintain a constant review of the Act and its application and of the immigration policy." This committee would advise the Government in regard to such changes in the law that the Government would propose or that the committee would feel to be necessary. It is recommended that a Royal Commission be established to study the Act and its application, or failing this a parliamentary committee, in order to make to the Act or to its application, the necessary changes.

The delegates to the T.L.C. strongly blamed the present immigraticn policy. Principal grievance: many Canadians are out of work while immigrants are pouring into the country. The Congress therefore protests strongly "to the Immigration authorities who permit foreign labour to work in Canada before being assured that among the unemployed there are no Canadian citizens available to fill these jobs. Amcng other things, the Congress recommends the complete revision of the Immigration Act and the restriction of immigration during winter and the off-season months. Finally, the creation of a government commission is requested on which would be represented the workers, the employers and the government.

\section{f) Unemployment Insurance}

The T.L.C. demands that coverage for unemployment insurance be extended to apply to all workers gainfully employed in all occupations. It was also requested that seasonal workers be entitled to benefits under the same conditions as workers in other employment, without having been obliged to make 180 contributions. Requests were also made that the waiting period be eliminated and that benefits be paid to workers "discharged during a legal strike"; recommendation was made to increase the benefits by $50 \%$.

The delegates to the C.C.L. had to vote on the recommendations of their committee on unemployment insurance. This committee recommended, among other things, to eliminate non-compensable days 
and to shorten considerably the waiting period if not to eliminate it completely; to extend the provisions of the Act to hospital employees; to extend the area of union rights under the Act, in order to protect the workers who refuse to cross the picket line of another union, etc., to add a sickness-disability scheme to supplement unemployment insurance.

Many resolutions concerning the Act were presented during the convention of the C.C.C.L. Let us quote some of them:

a) That benefits be increased by $\$ 1.00$ per week, in the case of an insured person without a child, by $\$ 3.00$ if the insured person has a dependent and by $\$ 6.00$ per week in the case of an insured person with two dependents, without an increase in the contribution.

b) That the period of supplementary benefits be extended to April 30th.

c) That after having eliminated the waiting period, all noncompensable days be eliminated even in the case of a worker who is only on part-time.

d) That the waiting period be reduced to three days before receiving benefits and that benefits be paid within fifteen days at the maximum from the date of the claim.

e) That in the case where an employer of whom the employees are on strike decides to discharge these employees, that the Act in article 39 , permit these employees to be paid unemployment insurance benefits.

Furthermore when the employees are on strike, an employer could not make use of the National Employment Service, by advertising under its authority. Moreover, the Service could not send him any candidates.

\section{Cost of living and price control}

The T.L.C. recommends the return of price controls and requests that federal subsidies be paid in order to reduce the price to the consumer of essential food items.

The C.C.L. declares: It is resolved that the Congress request the Federal Government to re-establish price control.

\section{Labour relations, wages, hours and working conditions}

a) T.L.C.:

The delegates of the T.L.C. demanded the establishment of a National Labour Code in order to secure more uniformity in labour 
legislation all over Canada. A demand was made also for the establishment of the five-day, 40-hour week, with national minimum wage of 85 cents per hour and the right for the worker to two weeks paid holiday after one year of service. The workers would be paid for all statutory holidays and would receive double pay if obliged to work on these days.

The Congress approves the establishment of a standing committee on government employees and recommends that the latter be given the right to be certified and to negotiate collective agreements with their employers. Changes in existing legislation was called for to prevent Labour Relations Boards from "interfering with the internal working of unions applying for certification." The delegates also requested the government to reword the fair wage schedules accompanying government contracts "so that they compel an employer to adhere to union agreements effective in the district." The Eastern Canadian Labour centres were requested to have minimum wage rates revised and "brought in line with the Western provinces".

b) C.C.L.:

Many resolutions were adopted at the C.C.L. convention on the subject of wages, working conditions and legislation. It was requested that the British North America Act be amended and provincial legislation be replaced by three new federal acts, of which one would set up a National Labour Code concerning all industries. Another would legislate on the 40-hour week with compulsory overtime rate for additional hours. Finally, a third act would establish an appropriate national minimum wage all over Canada. The government was requested to adopt a policy of fair employment practices, first in sanctioning a national law on this subject, by inserting non-discrimination clauses in all government contracts and by applying strongly the clauses contained in the Unemployment Insurance Act in regard to the activities of the National Housing Service.

The Congress condemned the tendency in certain provinces to get around labour rights by the use of injunctions and appeals to the courts and it trusts that every possible method of maintaining these rights will be used against the improper use of the courts by the employers and the government.

The C.C.L. also adopted a preconcerted project of organization in Quebec. Such a campaign was one of the projects already announced 
by the T.L.C., during its convention last August. The Congress is of the opinion that the labour movement of the Province of Quebec is menaced by "the anti-union activity of the provincial government".

\section{c) C.C.C.L.:}

It was particularly question of labour problems in our province at the last convention of the C.C.C.L. which recruits the majority of its members in the Province of Quebec. Different reports on these subjects were adopted by the delegates. Let us note the most important parts: "The use of the right of association is not effectively protected in our province. The suspensions and dismissals for union activity are too numerous. Many wrongs could be avoided if an Industrial Relations committee were created in the Legislative Assembly, and if a list of names of magistrates, judges and other competent persons were drawn up to act as presidents of arbitration councils when the parties cannot agree on the choice of the third arbitrator. These arbitrators could be chosen among the judges of all the courts of the Province. Another report emphasizes that "because of the anti-union atmosphere that has been developed in the province since a few years, some employers take advantage of it to attempt to get rid of the union which groups their workers".

On the other hand, it is to be feared that by the numerous accumulated postponements before the Labour Relations Board or arbitration councils, "it is practically equivalent to denying them the right to strike and because of this their right to belong to a union." For example "Employers in bad faith have seen in the use of injunctions an excellent method of dragging out indefinitely the legal delays".

Mr. Jean Marchand states on this subject "we would prefer, as the C.C.C.L. requests, that injunctions be abolished completely in cases of legal strikes".

The experience with arbitration councils is disastrous, and unless "a reform is undertaken in the near future, we fear that the institution itself may be definitely compromised".

Resolutions request that the practice of the Right of Association be recognized and that the employee dismissed for union activities be taken back in his former place with full restitution of his acquired rights in the enterprise and full compensation for loss of salary. 
Furthermore the Labour Relations Board would carry out itself all the necessary procedures to this effect.

Another resolution protests against the alarming delays in the administration of labour laws, "particularly in the arbitration procedures" and requests urgent and rapid reform.

The C.C.C.L. has also voted many resolutions that may be found in substance in the memorandum presented to the Government of the Province of Quebec:

a) That the law be amended so that the duration of collective agreements be for a definite period but less than three years.

b) An amendment to the law which would permit union organization in all towns entitled "company towns and lumber towns".

c) That the period of 14 days which follows an arbitration be reduced to 7 days.

d) To limit the settlement of grievances of public service employees to 60 davs.

e) An amendment to the law permitting the inclusion of superintendents and foremen as "wage-earners" in the definition of the law.

f) An amendment to the Ordinance No. 4, reducing from 54 to 48 hours, the hours of work of commercial employees.

g) That the employees in the woods work from 8 a.m. to 5 p.m. with an hour's rest at noon and that time and one-half be paid for overtime.

h) To increase the aid to apprenticeship centres in order to meet the growing needs of the existing centres.

i) Pressure brought on the Council of Public Education in order to secure a representative of the C.C.C.L. on the special committee of coordination of education.

\section{Union Education}

The T.L.C. called for the establishment of a labour college. 
The C.C.L. encourages the continued development of its Education department and requests that more emphasis should be directed towards basic trade-union history, structure and practices of unions. Union education should take on more importance in the unions themselves. Labour Councils and Federations should be encouraged to take hold of their own education programmes.

The C.C.C.L. announced a labour education manual of which the aim will be "to make a solid foundation for our effort in union education." In order to insure progress, permanence and unity in labour education, the Education department proposes the following objectives to the unions:

a) Increase the regional education departments inside each central council "which is the best placed organization in our movement to fill this most important union function."

b) Complete by way of schools of Labour Action the study of labour problems introduced in study circles. Spread the initiative of the Labour Action school destined for feminine members of unions.

c) Repeat the successful initiative of specialized study sessions for the permanent members of the movement.

d) Delegate members to the Labour College inaugurated at Quebec during the month of November. ${ }^{4}$

e) Organize schools for shop stewards, the front-line union fighters, because they need specialized training in order to ensure that the movement carries on and that they may train the masses.

f) To procure the manual dealing with Collective Labour Agreement to appear next autumn.

The report makes favourable mention of the considerable and precious aid received from the Centre de Culture Populaire de Laval

(4) Editor's Note: The Labour College has been such a success that it is to be desired that it be established on a permanent basis, and that it may function the wrole year round. 
(Extension Department), of which the aim is to contribute to the formation of a popular elite, by all ways at its disposition, and in particular, by permitting many professors to participate in the work of education undertaken by the union movements.

\section{Other resolutions}

T.L.C.:

1) The convention requests the Federal government to do everything in its power to obtain world peace through the United Nations and the Atlantic Pact.

2) The government should adopt measures destined to a) prevent unemployment; b) to give aid to under-developed countries; c) to expand our foreign trade; d) to aid in the establishment of new industry where such industry would further the development of the country's natural resources.

3) All the enterprises of telephone service should be nationalized. C.C.C.L.:

The Confederation proposes resolutions:

1) In view of obtaining maternity allowances and to increase the allowances to needy mothers by $50 \%$.

2) To have the government insist that Canadian Ship-owners build and repair their boats in Canada, by Canadian shipyards.

3) To amend the law concerning government annuities and raise the maximum to $\$ 2,400.00$.

4) To fix the municipal valuation of property, for taxation purposes, not on the value or cost of the property but in accordance with the income it earns and in the case of one-family properties, on its rental value; to remit $50 \%$ of the revenue from the sale of automobile licenses to the municipalities where the automobilists live as well as $50 \%$ of the revenue from the gasoline tax on the gasoline sold within the limits of these municipalities.

5) To increase family allowances by $50 \%$ and continue them in the case of children who are still going to school as long as they continue to do so. 
6) To grant the right to vote to every person "from the age of 18 ".

7) To form a committee of strategy of the C.C.C.L. This committee would make recommendations, but could not bind the different bodies of the movement. It would be purely consultative.

We have just seen the resolutions and recommendations of the various labour organizations of Canada, T.L.C., C.C.L. and C.C.C.L., which have been passed during their respective annual meetings for 1952. It may be realized from this the importance of these conventions for the members themselves, in permitting them to join forces to reach their common objectives, for the leaders in giving them favourable new occasions to enter in direct contact with their members and for everyone, in letting be known the positions and tendencies of unionism in Canada in $1952 . *$

* Editor's Note: In this study, the author has referred to the following documents: The Canadian Unionist, Vol. XXVI, No. 9, Septembre 1952, No. 10, October 1952, Official Journal of the Canadian Congress of Labour, Hull ,Que. The Labour Gazette. Vol. LII, No. 9, September 1952, published by the Department of Labour, Ottawa. - The People's School, Bulletin No. 1, October 12, 1952, Bulletin No. 2, October 19, 1952, published by St. Francis Xavier Extension Department, Antigonish, N.S. - Procès-verbal, Trente-etunième session du Congrès de la C.T.C.C., Shawinigan-Falls, P.Q., 1952. The Trades and Labor Congress Journal, Vol. XXXI, No. 9, September 1952, No. 10, October 1952, Official Magazine of the Trades and Labor Congress of Canada, Ottawa. 